\title{
THE PATAGONIAN GLACIATIONS AND THE ONSET OF GENERAL QUATERNARY- TYPE GLACIATIONS ON THE GLOBE
}

N.A.Mörner'

CALDENIUS (1932) mapped four extensive and impressive glaciations from the Argentine-Chilian mountain chain (Fig.1). By analogy and supposed correlation with the Scandinavian chronology, he - unfortunately - named these stages the Initioglacial, the Daniglacial, the Gothiglacial and the Finiglacial. This implies that the last three stages would date at $20 \mathrm{Ka}, 13 \mathrm{Ka}$ and $10 \mathrm{Ka}$, respectively. FIDALGO \& RUGGI (1965) accepted this and proposed that the Initioglacial represented the early phase of the last glaciation in the northern hemisphere some $60 \mathrm{Ka}$ ago.

The mapping of CALDENIUS (1932) was masterly done and seems to be generally correct. The chronology, on the other hand, was completely hypothetical. Still (and in absence of anything else), the chronology of Caldenius has been widely used. Both MERCER (e.g., 1976) and CLAPPERTON (1983) have noticed this weakness.

We have taken up this problem and applied paleomagnetism on a number of localities and in a number of different projects. This includes both stratigraphies associated to the glacial moraines along the Andes and stratigraphies in the coastal region with loess deposition as possible signs of glaciations (Fig. 1).

First, we have identified at least 5 (not 4) main moraine zones, which we interprete as signs of glaciation or "ice ages". In the Lago Buenos Aires area (MÖRNER \& SYLWAN, 1987, 1989 and MÖRNER, 1989a), these five moraine zones include as many as 15 separate terminal moraine ridges, representing phases of the main glaciations. The oldest (outermost) moraine zone (a part of Caldenius Initioglacial complex) has a quite different geomorphological appearance and must be considerably older than the others.

The two moraine zones, our I and II, belonging to Caldenius Initioglacial, were both

\footnotetext{
${ }^{1}$ Paleogeophysics \& Geodynamics, Geological Institute, S-10691 Stockholm, Sweden.
} 


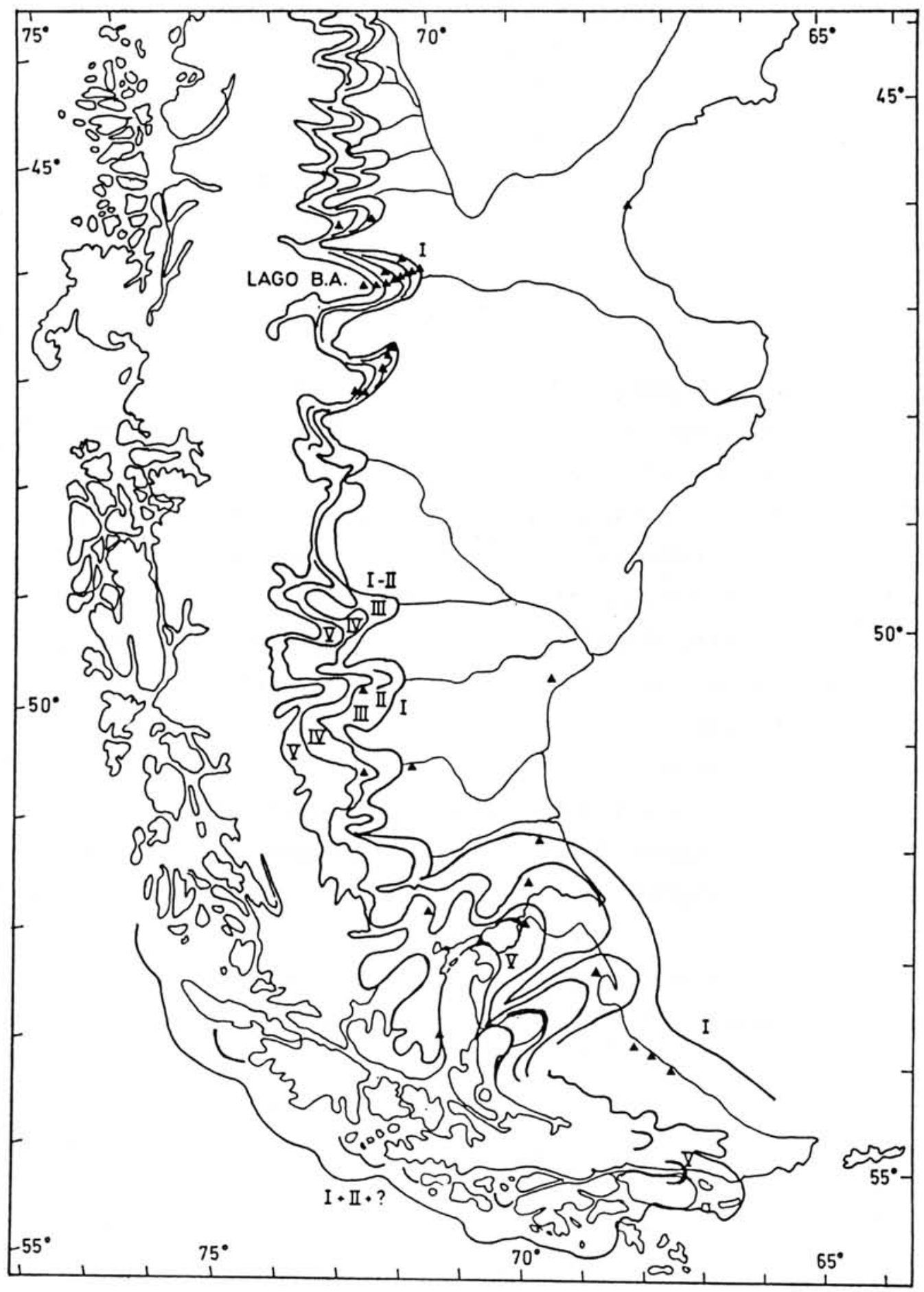

Figure 1 - Extension of the 5 glaciation maxima (I-V) in Patagonia (primarily as mapped by CALDENIUS, 1932). Black tringles mark localities investigated by us as to paleomagnetism and glacial chronology. The record from Lago Buenos Aires (Lago B.A.) serves as a type area. The first glaciation maximum (I) at about $2.3 \mathrm{Ma}$ had the widest extension and was the only one fully to cross the Tierra del Fuego area. 
formed during a period of reversed geomagnetic polarity. We believe that our zone I is of early Matuyama age or about $2.3 \mathrm{Ma}$ old, and that our zone II is of late Matuyama age or $1.2 \mathrm{Ma}$ old. This fits well with the occurrence of loess-like deposits in a magnetostratigraphically very well dated stratal sequence at Mar del Plata (RUOCCO, 1989 and RUOCCO \& MÖRNER, 1987). Our zone II glaciation (the first with a "fresh" appearance) would, in this case, correlate with MERCER's (1976) K/Ar dated maximum glaciation. BIDEGAIN (1989) has shown with magnetostratigraphy that an "old loess" in Entre Rios is of upper Matuyama age (fitting well with a $1.2 \mathrm{Ma}$ age of the zone II glaciation).

The zone III or "Daniglacial" glaciation is well fixed at the Brunhes/Matuyama transition; the initial phase being of reversed polarity and the main phase of normal polarity. This implies a fundamental and drastic revision of the old chronology. It has been recorded in several places and is considered a major and clear findings.

The zone IV or Gothiglacial glaciation remains undated. It occurred somewhere within the Brunhes Normal Epoch.

The zone V or "Finiglacial" glaciation includes several phases (as do the older zones), the last one of which must have ended shortly before about $14,000 \mathrm{BP}$ according to radiocarbon dates and secular paleomagnetic changes in a varved clay sequence of 887 individual varves (SYLWAN, 1987).

Our record from the Lago Buenos Aires area is shown in Figure 2 and the general chronology established for the Patagonian glaciations is shown in Figure 3.

From the paleomagnetic record at Mar del Plata (RUOCCO, 1989), we learn that cyclic alternations between wetter and dryer and between cooler and warmer periods began in the upper Gauss shortly after $2.9 \mathrm{Ma}$. This seems to represent a general climatic-environmental change (Fig. 2) and to be related to paleo-oceanographic changes, judging from the isotopic signals described by SHACKLETON \& OPDYKE (1977).

A short marine episode is determined at around 2.9-2.7 Ma both in the Parana basin (BIDEGAIN, 1989) and in Patagonia (MÖRNER et al., in prep.).

The system and chronology of glaciations established in Figure 3 does not indicate any clear correlation with northern hemisphere records nor with the oceanic high-frequency glacial/interglacial changes. This absence of correlation may be significant and real.

The late glacial and postglacial short-term glacial climatic changes seem rather to be out of phase than in phase with the northern European changes (MÖRNER, 1984, 1988) and to represent the redistribution of energy over the globe via ocean circulation changes (rather than globally synchronous rises and falls in temperature). This seems also to be the case with so-called Younger Dryas effects and correlations. It is true that the oceanic and atmospheric circulation was severely upset, but this lead to the redistribution of energy (heat) over the globe, not to a general fall over the globe. This concurs with the interpretation by MARKGRAF (1987) of the climatic changes in southern South America, but differ to the 


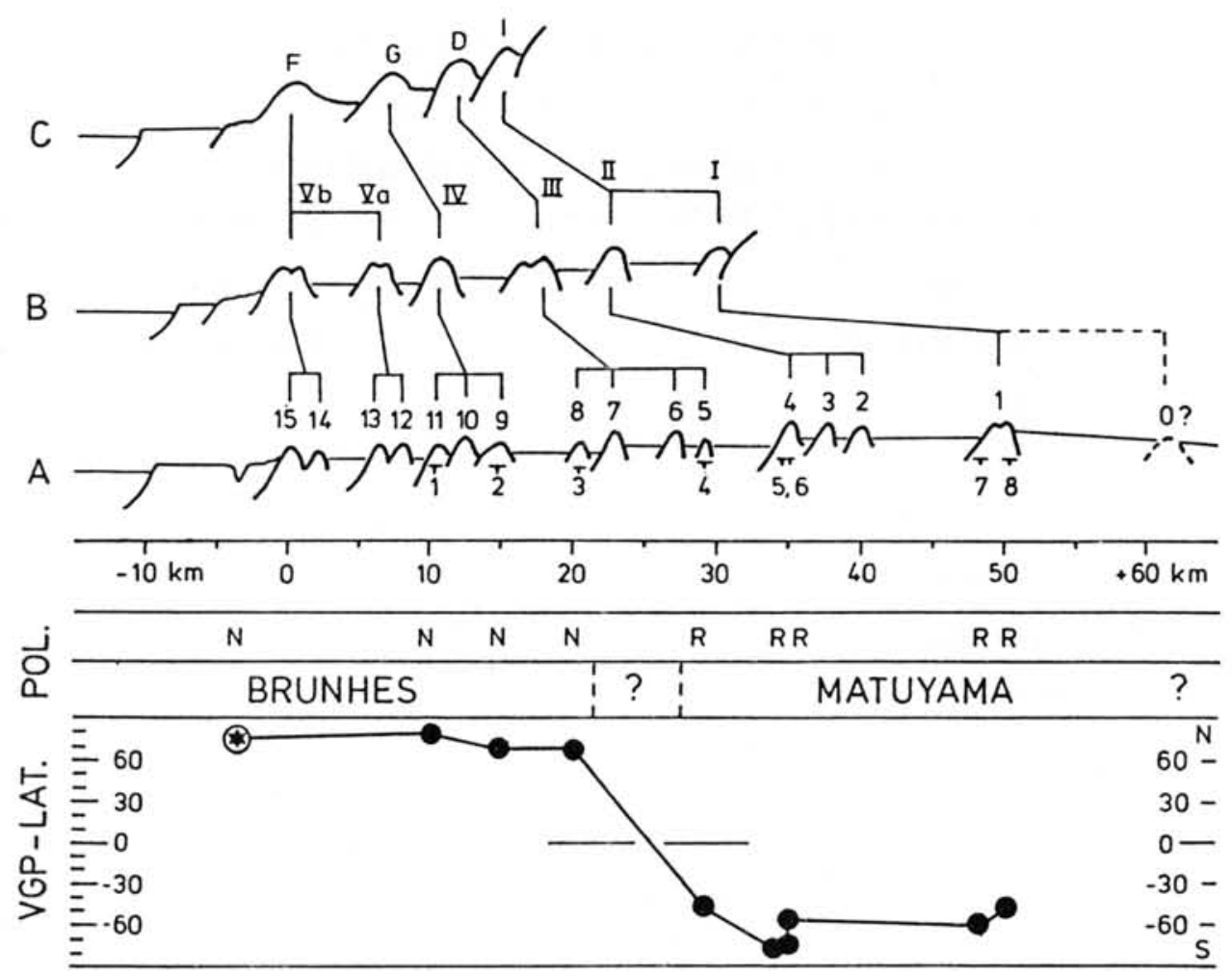

Figure 2 - Terminal moraines and moraines zones along three profiles (A-C) east to northeast of Lago Buenos Aires showing the change from 4 main zones (i.e., $F=$ Finiglacial, $G=$ Gothiglacial, $D=$ Daniglacial, $I=$ Initioglacial according to Caldenius nomenclature), to our five main zones (1-V) and 15 individual moraines (1-15). Horizontally bedded subtill proglacial sediments have been sampled for paleomagnetism in 8 localities (1-8). The distances are given with respect to the innermost moraine position. The paleomagnetic results (after complete demagnetization) are given at the base; the polarity records ( $N, R$ ) from the eight localities, the Brunhes-Matuyama zonation, and the VGP latitudinal record indicating a clear zonation between reversed and normal polarity (encircled star refer to our varved clay record). The Matuyama/Brunhes boundary occurred somewhere within the Daniglacial moraine zone (III).

interpretation by HEUSSER (1987).

In 1989, we extended our studies to the Antarctic Peninsula (MÖRNER et al., 1989a, 1989b) in connection with the Swedish Expedition (SWEDARP -88/89) to Antarctica. In the James Ross area, there was a maximum glacial expansion after the deposition of the "Pecten Conglomerate" on Cockburn Island. We believe that the marine episode that deposited the "Pecten Conglomerate" is identical to the events established all along the Argentine and Brazilian coasts (MÖRNER, 1989b) and dated at about 2.9-2.7 Ma (BIDEGAIN, 1989 and MÖRNER, 1989a). This is consistent with paleomagnetic data obtained from the "Pecten Conglomerate" and from possible correlative beds on Livingstone Island (MÖRNER, in prep.). The "Pecten Conglomerate" is covered by erratic material of a glacial phase of considerable size. This phase represents the maximum glaciation within this area. As it post-dates the Pecten Conglomerate, its age should be younger than $2.7 \mathrm{Ma}$ (provided the Pecten Conglomerate is properly dated). This is close 


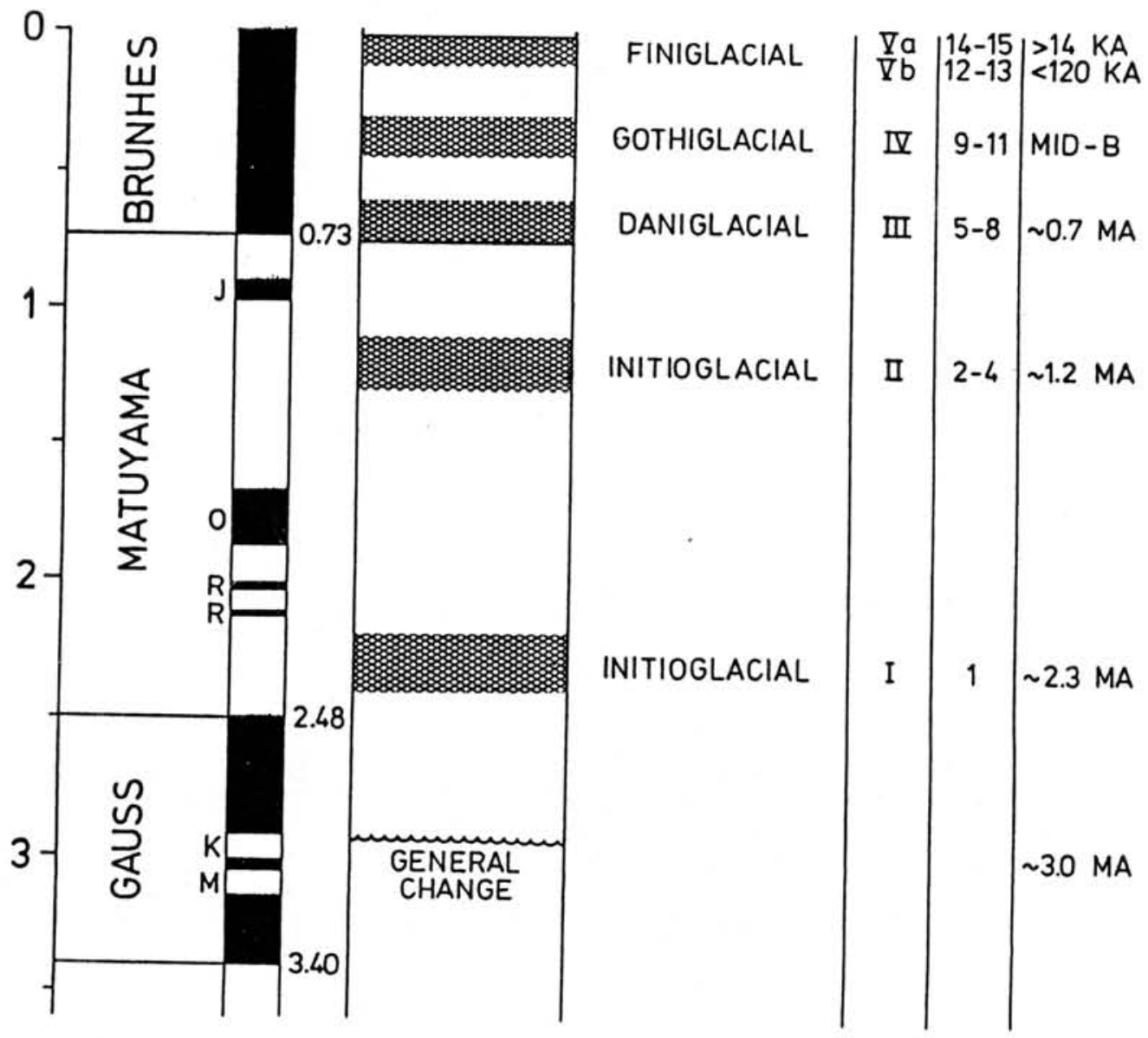

Figure 3 - Synthesis of the magnetostratigraphic position of the 5 main glaciations (or "ice ages") in Patagonia (oross-hatched zones), corresponding map-units according to CALDENIUS (1932), our numbering of the five moraine zones (I-V) and individual terminal moraines (1-15) in the Lago Buenos Aires area and ages of the 5 moraine zones (ice ages). The general change at around 3.0 Ma represents the beginning of an alternating climatic regimen. At about $2.9-2.8 \mathrm{Ma}$, there was a short but drastic marine episode.

to the established age of the maximum glaciation in Patagonia of about 2.3 Ma (MÖRNER, 1989a). The ice caps on the Antarctic Peninsula and in southern South America seen, therefore, to have reached their maximum at the same time. This seems quite reasonable, realizing that the first glaciation maximum in Patagonia was the only glaciation that crossed the entire Tierra del Fuego and exhibited a major dome in the south (Fig. 1).

Furthermore, the European and North American continental ice caps experienced a first maximum in the lowermost part of the Matuyama Reversed Chron at about 2.4-2.3 Ma. Similarly, the first loess beds in China began at about $2.4 \mathrm{Ma}$.

It seems, therefore, clear that the entire globe experienced a first glacial episode at about 2.4-2.3 Ma. This would, of course, be the logical lower boundary of the Quaternary. 
The paleomagnetic dating of the onset of glaciations in Patagonia, forms the base for presently available possibilities of establishing correlations both with Antarctica and with the northern hemisphere.

\section{REFERENCES}

BIDEGAIN, J.C. (1989) Magnetostratigraphy in Aldea Brasilera, Entre Ríos Argentina. In: INTERNATIONAL SYMPOSIUM ON GLOBAL CHANGES IN SOUTH AMERICA DURING THE QUATERNARY. São Paulo 1989. Special Publication, 1: Program, Abstracts and General Informations. São Paulo, ABEQUA/INQUA. 1989. p.46-48.

CALDENIUS, C. (1932) Las glaciaciones cuaternarias en la Patagonia y Tierra del Fuego. Geografiska Ann, 14:1-164.

CLAPPERTON, C.M. (1983) The glaciation of the Andes. Quaternary Science Reviews, (2):83-155.

FIDALGO, F. \& RIGGI, J.C. (1965) Los Rodados Patagónicos en la Meseta del Guenguel y Alrededores (Santa Cruz). Revista de la Asociación Geológica Argentina, 20:273-325.

HEUSSER, C.J. (1987) Climate of southern South America during the last glacial maximum inferred from pollen records. In: $12^{\text {th }}$ INQUA Congress, Ottawa, 1987. p. 186.

MARKGRAF, V. (1987) Paleoclimate data model comparison from the Southern Hemisphere. In: $12^{\text {th }}$ INQUA Congress, Ottawa, 1987. Abstracts, p. 220.

MERCER, J.H. (1976) Glacial history of southernmost South America. Quaternary Research, 6:125-166.

MöRNER, N.A. (1984) Climatic changes on a yearly to millennial basis. Concluding remarks. In: MöRNER, N.A. \& KARLÉN, W. (eds.) Climatic changes on a yearly to millennial basis. Dordrecht, D. Reidel. p.637-651.

MöRNER, N.A. (1988) Terrestrial variations within given energy, mass and momentum budgets; paleoclimate, sea level, paleomagnetism, differential rotation and geodynamics. In: STEPHENSON, F.R. \& WOLFENDALE, A.W. (eds.). Secular solar and geomagnetic variations in the last 10,000 
years. Dordrecht, Kuwer Acad.Press. .455-478.

MÖRNER, N.A. (1989a) The Patagonian glaciations. In: INTERNATIONAL SYMPOSIUM ON GLOBAL CHANGES IN SOUTH AMERICA DURING THE QUATERNARY. São Paulo, 1989. Special Publication, 1: Program, Abstracts and General Informations. São Paulo, ABEQUA/INQUA. p.164-167.

MöRNER, N.A. (1989b) Changes in the coastal sedimentary environments. The South American case and implications on Global Changes. In: INTERNATIONAL SYMPOSIUM ON GLOBAL CHANGES IN SOUTH AMERICA DURING THE QUATERNARY, São Paulo. 1989. Special Publication, 1: Program, Abstracts and General Informations. São Paulo, ABEQUA/INQUA. p.216-220.

MŐRNER, N.A. \& SYLWAN, C. (1987) Revised terminal moraine chronology at Lago Buenos Aires, Patagonia. Argentina. Intern. Proj. Paleolimnology and Late Cenozoic Climate, (4):15-16.

MÖRNER, N.A. \& SYLWAN, C. (1989) Magnetostratigraphy of the Patagonian moraine sequence at Lago Buenos Aires. Journal of South American Earth Sciences, 2(4):385-389.

MöRNER, N.A.; MUJICA, A.; DA ROCHA, P. (in press) Cenozoic magnetostratigraphy, sedimentary dynamics, paleoclimatology, sea level changes and related problems. SCAR report.

MöRNER, N.A.; MUJICA, A.; DA ROCHA, P. (in press) Paleomagnetism, sedimentary dynamics, paleoclimate and sea level changes. New approaches and results from the Antarctica Peninsula and South Shetland Islands. SCAR report.

RUOCCO, M. (1989) A 3 Ma paleomagnetic record of coastal continental deposits in Argentina. Palaeogeography, Palaeoclimatology, Palaeoecology, 72(1/2):105-113.

RUOCCO, M. \& MöRNER, N.A. (1987) Late Cenozoic litho-and magnetostratigraphy of continental deposits in Argentina. Intern. Proj. Paleolimnology and Late Cenozoic Climate, (4):14.

SHACKLETON, N.J. \& OPDYKE, N.D. (1977) Oxygen isotope and paleomagnetic evidence for early Northern hemisphere glaciation. Nature, 270:216-219.

SYLWAN, C. (1987) Annual paleomagnetic record from late glacial varves in Lago Buenos Aires, Patagonia, Argentina. Quaternary of South America and Antarctic Peninsula, 5:181-196. 